\title{
Die kwessie van Kaaps: Afrikaansonderrig op skool benodig 'n meer inklusiewe benadering The issue of Kaaps: Afrikaans teaching at school needs a more inclusive approach
}

\author{
Michael le Cordeur \\ Departement Afrikaans \\ Fakulteit Opvoedkunde, \\ Stellenbosch Universiteit \\ E-pos: mlecorde@sun.ac.za
}

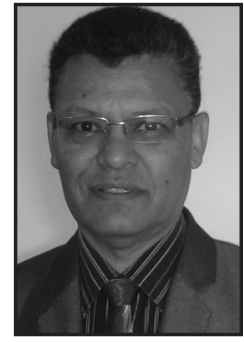

Michael le Cordeur

Michael le Cordeur is hoof van die Departement Kurrikulumstudies in die Fakulteit Opvoedkunde van die Universiteit Stellenbosch waar hy Afrikaansonderwys doseer en sy doktorsgraad in 2004 verwerf het. Voorheen was hy kringbestuurder van Onderwys in Stellenbosch. Sy navorsing en publikasies handel oor die bevordering van lees; taalbeleide; moedertaalonderrig en taalidentiteit. Hy is die skrywer of mede-skrywer van talle boeke en geakkrediteerde artikels en lewer verskeie referate op nasionale en internasionale vlak. As voorsitter van die Wes-Kaapse Taalkomitee speel hy 'n belangrike rol in die opstel van die Weskaapse Taalbeleid. Hy is een van die stigters van die Afrikaanse Taalraad en die Breytenbach Sentrum. Tans dien hy in die direksies van Het Jan Maraisfonds, die ATKV, die SA Akademie en die SBA. Hy is 'n rubriekskrywer vir verskeie koerante en gereelde kommentator oor taal en die onderwys. Le Cordeur is lid van die SuidAfrikaanse Onderwys Navorsings Vereniging (SAERA) en lid van die Internasionale Vereniging vir Navorsing oor Moedertaal-onderrig (ARLE). Vir die bevordering van Afrikaans ontvang hy verskeie toekennings: onder andere is hy bekroon met die Elisabeth Steijn-medalje van die SA Akademie, en die Universiteit van Stellenbosch het die prestige Kanselierstoekenning en vyf rektorstoekennings aan hom toegeken.
Michael Le CORdeur chairs the Department of Curriculum Studies in the Faculty of Education at Stellenbosch University where he teaches Afrikaans Education. He is a former Circuit Manager of Education in Stellenbosch and obtained a doctorate $(\mathrm{PhD})$ in 2004 at Stellenbosch University. His research and publications deal with reading skills, language policy, mother tongue education, and language identity. He is the author or co-author of various books and accredited articles and has read papers at various international and national conferences. As chair of the Western Cape Language Committee he played a pivotal role in drawing up the Western Cape Language Policy; he is a founder member of the Afrikaans Language Board and the Breytenbach Centre. Currently he is a board member of Het Jan Marais Trust, the ATKV, the South African Academy for Science and Arts (SAASA), and the SBA. A member of the South African Education Research Association (SAERA), the International Association for Research in First Language Education (ARLE) and a regular columnist on language issues, Le Cordeur received various accolades for his work: he was awarded the Elisabeth Steijn-medal by the SAASA; and received the Rector's Award for five consecutive years. In 2014 he received Stellenbosch University's prestigious Chancellor's Award. 


\section{ABSTRACT}

\section{The issue of Kaaps: Afrikaans teaching at school needs a more inclusive approach}

The universal context that this paper builds on relates to the theme of language as a form of cultural identity and the role it plays in education. The question that guides this research, is whether one variety of the Afrikaans language - referred to as Kaaps ${ }^{1}$ - is owned by its speakers in such a way that it not only underpins the individual and collective identities of those Afrikaans-speaking people classified as Coloured ${ }^{2}$ and marginalised by poverty, location and race, but it could also contribute to the successful delivery of the school curriculum in those schools attended mainly by the Coloured population. A socio-historical perspective on the history of the Kaaps language since the early 1600 s is reflected in a literature review, providing a backdrop to the current status of Kaaps among the coloured community; its rivalry with standard Afrikaans; the influence of Kaaps on its speakers' perception of their own identity; whether the CAPS makes provision for the teaching of Kaaps, and if so to what extent the language is used in South African schools.

From the earliest days of South African history political decisions were taken to ensure that White and Coloured and Black people lived apart from one another. The racial label "Coloured" inflicted deep wounds and created a lot of bitterness. Because Coloureds in the Cape lived apart from their fellow Afrikaans speakers for such a long time, the respective language communities also grew further apart: Kaaps eventually developed alongside Standard Afrikaans.

The earliest manifestations of Kaaps were recorded before Jan van Riebeeck set foot at the Cape on behalf of the Dutch East India Company (VOC) in 1652. At a time when most Afrikaners in Cape Town were becoming anglicised, Muslims played a large role in developing Kaaps. Despite the Dutch origins and lyrics of Cape Muslim music, this cultural contribution was never acknowledged and very little of it was documented.

The logical deduction following from these observations is that the "Coloured voice" simply could not be part of the canon of Afrikaans literature, because the Afrikaans spoken by most Coloured people (Kaaps) was regarded as a deviation from Standard Afrikaans. Most Coloured scholars are of the opinion that Standard Afrikaans does not represent the total language community of Afrikaans speakers. Yet the process of standardisation continued to deny the creole nature of Afrikaans, and the language was purified by the elimination of Khoi, Malay and slave influences. Another point of concern is that Kaaps is often disparagingly referred to as a joke language, thus conveying a stigma around the language. For many white speakers of Afrikaans the standard version of the language is part of their identity and defines who and what they are. It is no different for Coloured speakers of Afrikaans, but they are less outspoken about it. Against this background, the place of Coloured poets and writers who wrote in Afrikaans has always been controversial.

After 1994 schools were no longer separated and today integrated schools are a common phenomenon. But the legacy of apartheid education is still evident, for example, in the level of literacy in the Coloured and Black communities, which is much lower than that in the White communities. This is the result of years of non-development of language proficiency among Coloured people, because Kaaps was dismissed as sub-standard. This led to bitterness because

$1 \quad$ Kaaps is derived from "die Kaap" (the Cape).

2 According to Essak and Quayle (2007:73), the classification of social groups in terms of race is always problematic. The term "Coloured" here refers to people who were classified as "Coloured" in terms of apartheid legislation and must not be regarded as the author's approval of terms that label people on racial grounds

3 CAPS stand for Curriculum Assessment Policy Statements, the new curriculum used in South African schools (2011). 
children who grew up with Kaaps had to learn in Standard Afrikaans and the prescribed textbooks portrayed a different world to the one in which they lived.

A core aspect in the delivery of the curriculum is how knowledge is conveyed and constructed. Hence, several attempts were made to advance the recognition of Kaaps because the role of language is critically important in the successful delivery of the curriculum. Before learners can master a subject, they first need to overcome the barrier of the language of instruction. The result is that learners who speak Kaaps under-achieve in the national assessment tests because they are assessed in Standard Afrikaans.

It should also be determined whether or not the new CAPS curriculum allows for Kaaps to be taught at school. According to the CAPS (DoBE 2012:4) the curriculum is an all inclusive document that guarantees learners the right to knowledge, skills and values irrespective of their socioeconomic background. At the same time schools must be sensitive to issues such as diversity, language and race. The whole approach of CAPS is based on social transformation and human rights whilst teaching learners to appreciate our indigenous knowledge systems. Within this context it is clear that there is nothing that prohibits schools from acknowledging Kaaps in the curriculum.

It is widely recognized that learning through the mother tongue is the most effective form of learning with the best results (Alexander 1997, Heugh 2006). If this is true for English, Afrikaans, isiXhosa and all the other indigenous languages, the same argument holds true for Kaaps. It is against this background that this study calls for a better representation of Kaaps in the school curriculum.

KEYWORDS: Kaaps, varieties of Afrikaans, Standard Afrikaans, identity, "Coloured people", curriculum, Muslims, restandardisation

TREFWOORDE: Kaaps, variëteite van Afrikaans, Standaardafrikaans, identiteit, bruinmense, kurrikulum, Moesliems, herstandaardisering

\section{OPSOMMING}

Dit word wêreldwyd aanvaar dat moedertaalonderrig die beste resultate lewer. As dit waar is van Afrikaans, Engels, en ons inheemse tale, dan geld dieselfde argument ook vir Kaaps, die moedertaal van etlike miljoene sprekers. Die navorsingsvraag is of Kaaps in die skoolkurrikulum verreken moet word in die skole waar die leerders hoofsaaklik Kaaps as huistaal het, en indien wel, hoe moet dit geskied? Die metodologie behels 'n blik op die geskiedenis en huidige status van Kaaps; of daar ruimte is vir Kaaps binne die doelwitte van die KABV; die invloed van Kaaps op sy sprekers se persepsie van hul identiteit; die spanning tussen Kaaps en Standaardafrikaans te midde van die herstandaardiseringsproses; en tot watter mate Kaaps in Suid-Afrikaanse skole tot sy reg kom. Die studie bevind dat leerders wat met Kaaps grootword, benadeel word. Die studie beveel dus aan dat Afrikaansonderrig op skool 'n meer inklusiewe benadering moet volg, wat aan Kaaps sy regmatige plek in die kurrikulum sal gee.

\section{INLEIDING}

Die beginsel dat onderrig in ' $\mathrm{n}$ kind se moedertaal minstens vir die eerste ses jaar van sy skoolloopbaan onontbeerlik is vir ' $n$ kind se kognitiewe ontwikkeling, word wêreldwyd aanvaar (Bamgbose 2000, Cummins 2005, Heugh 2006). In hierdie opsig is dit betekenisvol dat die destydse Minister van Onderwys reeds agt jaar gelede erken het dat moedertaalonderrig leergeleentede ontsluit waarvan leerders voorheen uitgesluit was.

'n Kernaspek in die voltooiing van 'n kurrikulum is hoe kennis ontvang, gekonstrueer en 
oorgedra word (Le Cordeur 2015b). Kenners (vgl. Heugh 2006) is van mening dat die taal waarin die kurrikulum oorgedra word, die kern vorm van Suid-Afrika se onderwyskrisis. Leerders se voorafkennis is in hul taal opgesluit en moedertaalonderrig fasiliteer die verwerwing van kennis en begrip, en die ontwikkeling van kognitiewe, affektiewe en sosiale vaardighede (Webb 2006:39). Dieper vlakke van begrip stel leerders in staat om kennis van een konteks na 'n ander oor te dra (Bransford et al. 2000).

Volgens die Sensus-opname van 2011 is daar vandag byna 7 miljoen Afrikaanse Huistaalsprekers waarvan die oorgrote meerderheid, naamlik 4 miljoen, bruin mense is. Met 3 miljoen mense wat Kaapse Afrikaans as moedertaal praat, is Kaaps groter as vier van Suid-Afrika se ander amptelike tale en dus 'n moedertaal waarmee rekening gehou moet word. Die vraag moet gestel word of die kurrikulum genoegsaam getransformeer het om 'n bydrae te lewer tot die akademiese sukses van leerders wat met Kaaps opgegroei het. Mehrotra (1998) stel dit as volg:

... if the medium of instruction in school is a language that is not spoken at home the problems of learning in an environment characterized by poverty are compounded, and the chances of drop-out increase correspondingly.

Die algemeen erkende betekenis wat wêreldwyd aan 'n standaardtaal geheg word, is dat dit die taalvorm is wat geassosieer word met belangrike gebruikskontekste, soos akademiese taal, segstaal en onderrigmateriaal wat 'n sekere prestige-waarde geniet (Carstens 2011:285, Van Rensburg 1997:43). Standaardafrikaans is dus die variëteit van Afrikaans wat vir die hoë funksies gebruik word terwyl ander variëteite gewoonlik tot die laer funksies beperk is (Carstens 2011:82; Van Rensburg 1997:31).

In direkte kontras met hierdie siening sal ek in hierdie artikel argumenteer dat Kaaps, wat die moedertaal is van ongeveer 2,5 miljoen leerders, oftewel 'n groep gesinne in die Wes-Kaap wat in totaal 3,3 miljoen beloop, ook as skooltaal, oftewel taal van hoër funksies gebruik kan en moet word. Ek sal aanvoer dat Kaaps wyer erkenning moet kry in die kurrikulum. Nie net sal leerders wat Kaaps as huistaal praat, hul skoolloopbane met meer vertroue en meer sukses kan aanpak nie, dit sal ook lei tot verbeterde akademiese prestasie.

\subsection{Metodologie en navorsingsvrae}

Die navorsingsontwerp behels onder meer 'n selektiewe historiese ondersoek ten einde 'n aantal opvoedkundige en taalkundige kwessies, teorieë, en praktyke beter te kan begryp (Lin 2009:179). Die volgende vraag is ter sake:

\section{Behoort Kaaps in die skoolkurrikulum verreken te word, en indien wel, hoe?}

Die subvrae wat die outeur hierin gelei het, is: Hoe is Kaaps in die verlede in die skoolkurrikulum verreken (indien enigsins)? Wat was die gevolge hiervan? Hoe is daar sedert 1994 gepoog om dit reg te stel? Was hierdie maatreëls voldoende, en waarom (nie)? Wat behoort in die toekoms gedoen te word om groter erkenning te gee aan Kaaps?

\section{KAAPS EN DIE SKOOLKURRIKULUM}

\subsection{Kaaps kom van ver af}

Die vroegste Kaaps is reeds voordat Jan van Riebeeck in 1652 voet aan wal gesit het, opgeteken nadat Van Linschoten in 1592, en De Houtman en Lodewycks in 1595, die Kaapse kus besoek het. Met die aankoms van die eerste groep slawe in 1658 uit Angola en Mosambiek is Portugees 
na die Kaap gebring. Daarna is slawe uit die Ooste ingevoer wat Maleis na die Kaap gebring het (Van Rensburg 2012:26). Talle vryburgerboere is teen die einde van 1700 getroud met Khoi-Khoi vroue of voormalige slavinne wat toe reeds 'n ander vorm van Hollands (Kaapse-Hollands) gepraat het. Kinders het met die moeders se Afrikaans grootgeword. Dié Afrikaans staan vandag bekend as Kaaps (Van Rensburg 2012:36) en dit is die huistaal van meer as 3,3 miljoen mense in die Wes-Kaap (Le Roux \& Pissoa 2011).

Alhoewel die sprekers van Kaaps meestal bruin is, praat nie alle bruin mense Kaaps nie, terwyl daar ook talle wit sprekers van Kaaps is (vgl. Du Preez 2011). Daar is dus nie 'n oorsaaklike verhouding tussen velkleur en taal nie (Van de Rheede 1985). Dit is eerder 'n geval dat bruin Suid-Afrikaners, in die besonder dié van die Kaapse Skiereiland, oorwegend nie eentaalsprekers of eenvariëteitsprekers is nie maar wel oor 'n verbale repertoire beskik wat inhou dat hulle tussen Afrikaans en Engels en tussen variëteite van Afrikaans en Engels verskuif, ooreenkomstig die situasionele kontekste waarbinne hulle hul mag bevind (Hendricks 2009).

Sprekers van Kaapse Moesliemafrikaans, wat reeds vroeg in die 19de eeu vorm gegee het aan hierdie variëteit van Afrikaans deur gebruikmaking van die Arabiese alfabet, het volgens Kotzé (2014:647) 'n aansienlike bydrae gelewer tot geskrewe Afrikaans. Tog word hierdie belangrike komponent reeds met die heel eerste standaardiseringspogings van Kaaps-Hollands uitgesluit van die proses, wat 'n miskenning van die bydrae van 'n beduidende groep Afrikaansgebruikers behels.

Een van die eerste Afrikaanse manuskripte was die Moesliems se Heilige Koran. Baie slawe het die Islamitiese geloof aangeneem (vgl. Die slavin, Philida, in André P. Brink se laaste boek met dieselfde naam as titel) en het uit die Koran geleer om teksgedeeltes en godsdiensgebruike uit te skryf (Le Cordeur 2011a). Die Kaapse Moesliemgemeenskap begin gevolglik reeds in 1793 met die Madrassa (Moesliemskool) in Dorpstraat, Kaapstad. Dit was die eerste skool waar in Afrikaans klasgegee is (Davids 2011:68). Die oudste vertaalde Afrikaanse teks is die Bayān al-Dīn. (Uiteensetting van die Geloof) wat deur Abu Bakr Effendi in Arabiese skrif geskryf is (Van Rensburg 1997:13). Moesliems het ook 'n groot rol gespeel om Nederlandse liedere te bewaar (I.D. du Plessis, 1935). In 'n tyd toe die meeste Afrikaners in Kaapstad verengels het, het Moesliems Maleierkore gestig (Davids 1994:40). Een van die bekendste Nederlandse liedere is Rosa, 'n minnelied wat op feeste en bruilofte gesing word. Ten spyte van die Hollandse oorsprong en lirieke van Kaapse Moesliem-musiek, het hierdie kultuurbydrae nooit erkenning gekry nie, hoofsaaklik weens die sosiale ongelykhede, asook godsdiensverskille. Moesliemafrikaans het dus tot 'n groot mate verlore gegaan en min daarvan is opgeteken as deel van Standaardafrikaans (Kotzé 2014:648).

\subsection{Kaaps en die KABV-kurrikulum}

Dit is raadsaam om eers vas te stel in welke mate - indien enige - die Kurrikulum Assessering Beleidsverklaring (KABV - oftewel CAPS) voorsiening maak vir die verrekening van Kaapse Afrikaans.

\section{Agtergrond}

Die KABV vervang alle vorige kurrikula (DvBO 2012:3) en vorm die grondslag van die kennis, vaardighede en waardes wat noodsaaklik is om te leer. Hiervolgens bevorder die kurrikulum die idee van kennis binne plaaslike, bekende kontekste en toon terselfdertyd sensitiwiteit vir diversiteit (Le Cordeur et al. 2014:19). 
Die volgende doelwitte van die KABV dien as redes vir die gebruik van Kaaps in die skool:

- om leerders, ongeag hul sosio-ekonomiese agtergrond, fisiese of intellektuele vermoë, toe te rus met die kennis, vaardighede en waardes wat nodig is vir selfvervulling en betekenisvolle deelname in die samelewing as burgers van 'n vrye land;

- om sensitief te wees vir kwessies wat diversiteit weerspieël soos armoede, ongelykheid, ras, geslag, taal, ouderdom, gestremdhede en ander faktore (DvBO 2012:4).

Voorts verwag die KABV van leerders om probleme te identifiseer en op te los; om besluite te neem deur kritiese en kreatiewe denke; om doeltreffend saam met ander as lede van 'n span of groep saam te werk; hulself doeltreffend te organiseer en te bestuur; om inligting te versamel, te ontleed en krities te evalueer; en om doeltreffend te kommunikeer deur middel van visuele, simboliese en/of taalvaardighede in verskillende vorme (DvBO 2012:8). Dit is duidelik dat hierdie almal hoë-orde kognitiewe vaardighede is wat slegs deur middel van die leerder se huistaal - in hierdie geval Kaaps - gedoen kan word.

\section{Rasionaal vir die onderrig van tale}

Binne die konteks van die KABV is taal dus 'n instrument vir denke en kommunikasie. Dit is ook 'n kulturele en estetiese middel wat mense deel sodat hulle beter sin kan maak van die wêreld waarin hulle leef. Die doeltreffende gebruik van taal stel leerders in staat om kennis te verwerf, hulle identiteit, gevoelens en idees uit te druk, in interaksie te tree met ander en ook om hulle eie leefwêreld te bestuur. Dit voorsien leerders van 'n ryk, kragtige en diepgewortelde stel beelde en idees wat hulle kan gebruik om hulle wêreld te verander en te verbeter. Volgens die beginsels van die KABV stel taal leerders in staat om uitdrukking te gee aan kulturele diversiteit en word sosiale verhoudings opgebou en aangeknoop (DvBO 2012:8). Hierdie doelwitte is slegs moontlik as die leerder in sy huistaal (Kaaps) kan leer.

Verder beklemtoon die KABV die gebruik van Huistaal in die skool omdat dit taalvaardighede fasiliteer wat basiese interpersoonlike kommunikasievaardighede en kognitiewe akademiese vaardighede reflekteer. Basiese interpersoonlike kommunikasievaardighede word benodig in sosiale situasies, en kognitiewe akademiese vaardighede is nodig vir leer oor die kurrikulum heen (DvBO 2012:8). Ook om hierdie rede is die leerder afhanklik daarvan om in Kaaps (sy Huistaal) te leer pleks van Standaardafrikaans.

Ons kom dus tot die slotsom dat die KABV juis voorsiening maak vir die verrekening van Kaaps in die skoolkurrikulum. Die vraag is hoe moet dit gedoen word?

\subsection{Aparte woongebiede, aparte tale}

Weens die groepsgebiedewet het bruin, swart en wit leerders in die apartheidsera afsonderlike skole bygewoon. Die Wet op Swart Onderwys (Wet No. 47 van 1953) het swart onderwys afgesonder. Dit was swak befonds en die gehalte van die onderwys was minderwaardig in vergelyking met dié van alle ander groepe. Wit onderwys het byvoorbeeld heelwat meer fondse van die regering ontvang (Carstens \& Raidt 2015).

Ná 1994 het die skeiding in skole begin verdwyn en vandag is geïntegreerde skole'n algemene verskynsel. Die nadraai van apartheidsonderwys sal egter nog lank met Suid-Afrika wees, want

$4 \quad$ Hier word slegs die gedeeltes wat van toepassing is op Kaaps aangehaal. 
na 21 jaar van demokrasie, is sommige swart skrywers (vgl. Mannya 2015:8) van mening dat ons woonbuurte steeds eeue van mekaar verwyder is. Mense wat ver weg van mekaar woon, sien en ervaar die wêreld verskillend van mekaar (Pienaar 2014).

Deur vir solank apart van hul mede-Afrikaanssprekendes te woon, sou dit daartoe lei dat die Afrikaanse gemeenskap verder van mekaar gegroei het - ook in terme van Standaardafrikaans teenoor Kaaps. Dit is nêrens meer sigbaar as in die klaskamer nie. Die taalhandboek is vir die meeste leerders wat Kaaps praat, vreemd. Hulle sien woorde wat vir hulle vreemd is en is genoodsaak om aanpassings te maak (Le Cordeur 2012).

\title{
2.4 Kaaps versus Standaardafrikaans
}

Die verhouding tussen Kaapse Afrikaans en Standaardafrikaans is soos die verhouding tussen die Afrikaner en sy bruin medeburgers: dit loop hand aan hand. In een van sy heel vroegste gedigte verwoord SV Petersen die gevoel van die bruinman teenoor sy wit werkgewer en verwys na die bloedverwantskap tussen die twee:

\author{
Weet dit \\ vir my bly jy 'n vreemdeling, niks meer; \\ jou vader was 'n slaaf, \\ en myne was 'n heer!" (Uit: Verwantskap, ${ }^{5}$ 1944)
}

Dit was Langenhoven (Hugo 2009:65) wat in die vroeë $20^{\text {ste }}$ eeu gesê het dat Afrikaans die grootste enkele prestasie is wat nie saam met die witman van oorsee af gekom het nie. Sedertdien is Afrikaans deur verskeie skrywers as 'n witmanstaal bejeën. Afrikaans sou ook gebrandmerk word as die taal van die apartheidsregering en die taal van die onderdrukker, veral omdat Afrikaans op rassegrondslag bevorder is. Standaardafrikaans was volgens Odendaal (2014:663) van die begin af gestempel as 'n witmanstaal. So byvoorbeeld het S.J. du Toit onomwonde verklaar dat hy hom hou aan die "taal van die boere", en J.H.H. de Waal verwys na Afrikaans as "die taal van die Afrikaander" (Odendaal 2014:664). Ook Van Rensburg (2012:43) is van mening dat die variëteit wat die basis vorm van die huidige Standaardafrikaans, naamlik Oosgrensafrikaans, 'n wit taal was.

Tydens die bewind van die Nasionale Party het Afrikaans amptelike status verkry, alhoewel dit deur net 13\% van die bevolking gepraat is. ${ }^{6}$ Terwyl Standaardafrikaans deur die apartheidsregering bevoordeel is, het variëteite soos Kaaps nie dieselfde erkenning gekry nie. Dit het trouens 'n ondergeskikte posisie in die standaardiseringsproses ingeneem (Odendaal 2014:664). Odendaal (2014:658) haal Parakrama (1995:162) aan wat beweer dat "die standaardtaal teen minderheidsgroepe en gemarginaliseerde groepe diskrimineer, aangesien dit gewoonlik op die variëteit gebaseer is wat deur die ekonomiese, politieke en kulturele of sosiale elite in die samelewing verkies word en hulle dus daardeur bevoordeel word".

Odendaal (2012) verklaar derhalwe "standardisation is not merely a technical exercise - it is politically motivated". Hierdie standaard, sê sy, verteenwoordig nie die totale spraakgemeenskap van Afrikaans nie. Du Preez (2011) bevraagteken ook die beheptheid met Standaardafrikaans en baseer haar standpunt op die feit dat bruin Afrikaanssprekendes verreweg in die meerderheid is

Vervat in die bundel Die enkeling, 1944.

Volgens die 2011 Sensus verteenwoordig Afrikaans 13,45\% van die totale bevolking van Suid-Afrika. In vergelyking met die twee grootste tale in Suid-Afrika, isiZulu (22,7\%) en isiXhosa (16\%) is dit maar derde. Engels met 9\% is gelykstaande aan Sepedi (9.06\%) terwyl Setswana en SeSotho (albei $8 \%$ ) ook groot tale is. 
in die Wes-Kaap: 'Why is it so important to preserve the standard variety whilst 'Kaaps' is the mother tongue of over three million people in the Western Cape?"

Die verskille tussen Standaardafrikaans en Kaaps het daartoe gelei dat Kaapssprekende leerders agtergekom het dat hulle 'n ander "taal" moet aanleer, waaraan hulle taalvaardigheid gemeet sou word wanneer hulle na 'n Afrikaanse skool gaan (Van Rensburg 1997:187, aangehaal in Odendaal 2014:665). Gevolglik het 'n groot groep Kaapssprekende ouers aan die einde van die twintigste eeu hulle sterk begin uitlaat omdat hul kinders wat met Kaaps grootgeword het, na die standaardvariëteit moes oorskakel (Esterhuyse 1986) as hulle in die klas sit, maar nie almal kon hierdie transmissie ewe suksesvol doen nie (Hendricks 2012). Onder andere het voorgeskrewe boeke ' $n$ ander leefwêreld uitgebeeld as dit waarmee hulle kinders opgegroei het. In hierdie opsig haal Odendaal (2014:665) vir Bamgbose aan (2000:16) wat na omgangsvariëteitsprekers van Afrikaans as die "magteloses" verwys, aangesien kinders nie deur middel van hul moedertaalvariëteit onderrig ontvang nie. Alvorens leerders die vak kan bemeester, moet hulle eers die hindernis vir leer, d.w.s. die taal van onderrig, oorkom (Heugh 2006). Gevolglik sukkel die leerders om in die skool aan te pas, wat 'n negatiewe invloed op hulle kognitiewe en affektiewe ontwikkeling het (Le Cordeur 2014b).

Odendaal (2014:665) verwys na Webb wat aanvoer dat die sosiopsigologiese gevolge verbonde aan die dwang om op skool net 'n sekere variëteit te gebruik, ook nie uitgesluit kan word nie. Dit sluit in gebrek aan selfvertroue, 'n lae selfbeeld, en uiteindelik akademiese mislukking. Die rol van taal (Kaaps) is dus van kritieke belang vir die suksesvolle voltooiing van die kurrikulum, want dit beïnvloed die akademiese sukses van meer as 2,5 miljoen leerders.

Odendaal (2014) noem voorts dat verskeie pogings sedert die 1980's aangewend is om ander variëteite van Afrikaans te erken. Desondanks het standaardisering voortgegaan om die kreoolse aard van Afrikaans te ontken, terwyl die taal gesuiwer is van Khoi en Maleisiese en slawe-invloede. Op grond van hierdie suiweringsproses is Standaardafrikaans gesien as "beskaafde" Afrikaans, teenoor ander variëteite (soos Kaaps) wat as "onbeskaafd" beskou is.

Die standaardisering van Afrikaans het dus met sosiale ongeregtigheid gepaardgegaan (Kotzé 2014:648) waarvoor die taal 'n duur prys betaal het: die vervreemding van die variëteitsprekers (Odendaal 2014:665). Hierdie vervreemding is die duidelikste sigbaar in die skoolsituasie. Volgens Giliomee (2014:580) is daar onder bruin mense 'n sterker groeiende vereenselwiging met Engels as 'n taal van studie en taal van werk. Hieruit word dit duidelik dat so lank as wat Kaaps in die skool as "onbeskaafd" gestigmatiseer word, bruin mense toenemend Afrikaans die rug sal toekeer (Le Cordeur 2015b:3).

Hendricks (2009) voer gevolglik aan dat 'n toekomstige herstandaardisering van Afrikaans haas onvermydelik is. Odendaal (2012) stem saam. Volgens haar behoort die herstandaardisering van Afrikaans te fokus op normatiewe en ideologiese taalbeplanning wat die behoeftes van die totale spraakgemeenskap in ag neem. Sodoende sal die herstandaardisering van Afrikaans lei tot die bemagtiging van al sy sprekers; op sielkundige, ideologiese, ekonomiese en akademiese gebied. Voorts sal dit lei tot wyer erkenning van Kaaps binne die skoolomgewing.

\subsection{Die stigmatisering van Kaaps}

In die vorige afdeling is daarop gewys dat die Standaardiseringsproses Afrikaans wou "suiwer" van Khoi, Maleisiese en slawe-invloede m.a.w. nie-standaardafrikaans is gestigmatiseer as sou dit minderwaardig, selfs onbeskaafd wees. Alvorens mens van Kaaps as skooltaal kan begin praat, moet die stigmatisering van Kaaps eers laat vaar word. Volgens Le Cordeur (2015b:3) is dit juis oor die miskenning van hul taal dat sommige studente by die universiteit hulle skaam vir hul taal. 
Daar is al herhaaldelik gepleit dat die stigmatisering van Kaaps laat vaar moet word omdat dit die sprekers van die taal aanstoot gee (Odendaal 2012, Le Cordeur 2013). Willemse (2011) het selfs die media gevra om 'n bewusmakende rol te speel teen die stigmatisering. Ten spyte van die pleidooie kom die stereotipering van Kaaps en sy sprekers steeds in die media voor.

Dat (onbedoelde) stereotipering selfs voorkom in resensies blyk uit Joan Hambidge (2013) se resensie van Nathan Trantraal se bundel Chokers en Survivors - sy het naamlik na sy Kaaps as "gangster-taal" verwys. Nòg Hendricks, nòg Trantaal (Rapport 2013b) stem hiermee saam. Hendriks stel dit so: "Met die gelykstelling van Kaaps aan bendetaal kan ek my nie vereenselwig nie. Kaapse bendetaal is maar een register-onderskeiding in Kaaps."

Die waarheid is dat van ons bekendste bruin gemeenskapsleiers, digters en politici Kaaps praat. Nathan Trantaal (Rapport 2013b) reageer as volg op Breyten Breytenbach en Joan Hambidge: "Ek is die een Afrikaanse skrywer wat in 'n goeie posisie is om enigiets oor Kaaps en sy literêre werke te sê ...want ek praat die taal en leef daarin". Die woorde van die digter, dramaturg en Hertzogpryswenner, Adam Small - reeds 50 jaar gelede geuiter - sou diegene wat Kaaps as onbeskaafd stigmatiseer, teregwys en daarom is dit gepas om dit hier te herhaal:

Kaaps is 'n taal, 'n taal in die sin dat dit die volle lot en noodlot van die mense wat dit praat, dra; die volle lot, hulle volle lewe 'met alles wat daarin is'; 'n taal in die sin dat die mense wat dit praat, hul eerste skreeu in die lewe skreeu in hierdie taal, al die transaksies van hulle lewens beklink in hierdie taal, en hulle doodsroggel roggel in hierdie taal. Kaaps is nie 'n grappigheid of 'n snaaksigheid nie. (Adam Small, Kitaar my kruis, Woord vooraf, 1962).

\title{
2.6 Die marginalisering van Kaaps en sy sprekers
}

Die rol van bruin mense in die ontwikkeling van Afrikaans is nooit werklik erken nie. Dit desnieteenstaande die feit dat die aantal bruin lesers van 'n Afrikaanse dagblad soos Die Burger gegroei het van net $25 \%$ aan die begin van die 1990 's tot die huidige meer as 50\% (Giliomee 2014:583). Dit lei tot ongelukkigheid by bruin Afrikaanssprekendes en dit is geen wonder dan dat bruin Afrikaansprekendes "steeds soos bywoners in hul eie taal voel" nie (Le Cordeur 2013; Odendaal 2014:669; Kapp 2013:189). Die etiket van bruinwees het diep wonde en baie bitterheid geskep, soos blyk uit die volgende gedig:

\author{
Laat dit dan wees, o Heer, dat ek \\ 'n duisend jaar gelee teen God \\ en mens gesondig het ... \\ dan weet ek tog, dis u besluit, \\ die vloekstraf van 'n donker huid. (uit: Bede, SV Petersen. 1944)
}

Wat dit beteken is dat ongeveer 3,3 miljoen mense vir wie Kaaps 'n huistaal, 'n godsdienstaal, 'n kulturele taal, en 'n emosionele taal is, se opinie dikwels geïgnoreer word wanneer daar oor Afrikaans besin word. Dit is tekenend van sommige Afrikaner-meningsvormers wat steeds hulself as die leiers in die gesprek oor Afrikaans beskou en verwag dat ander groepe en variëteite by "hulle" inskakel. Dit sluit aan by Pierre Bourdieu (1991) se siening (soos aangehaal deur Kotzé 2014:639) wat verwys na 'n spreker se "posisie" in die samelewing wat die voorrang bepaal van 'n spreker om gehoor te word. In Suid-Afrika is bruin en swart mense nog altyd gesien as ondergeskiktes en hul mening is selde in ag geneem.

In die ouer Afrikaanse kritiek was daar nog openlike rassekategorisering. In Dekker (1966:292) se literatuurgeskiedenis word op 'n neerhalende wyse na SV Petersen se bydrae verwys as die "die stem van die Kleurling wat nog ongeskoold" sou wees en nog nie "werklike poësie" is nie. 
Deur Small te tipeer as "swart Sestiger" (Dekker 1966:292), word sy bydrae tot een van die bloeitydperke in die Afrikaanse letterkunde wel erken, maar dit impliseer ook sy marginalisering in daardie letterkunde: 'n posisie van binne maar tog ook buite. Dinge sou egter verander.

Die struggle in die algemeen en die opstande van 1976 in besonder sou aan die sprekers van Kaaps 'n nuwe stem gee. Die Soweto-opstand op 16 Junie 1976 het na die res van die land oorgespoel en dit word vandag steeds geëtiketteer as protes teen 'n taalbeleid wat Afrikaans op swartmense afgedwing het (Van Rensburg 2012:133). Bruin Afrikaanssprekendes het ook hulle stem gevoeg by die groter swartbewussynsprotes en opstand op die uitgestrekte Kaapse Vlakte het toegeneem. In hierdie tyd was dr. Allan Boesak vir baie bruin Afrikaanssprekendes die simbool van hulle deelname aan die bevrydingstryd. Sy legendariese woorde by die Wêreldraad van Kerke dat hy sal veg teen apartheid, is in Afrikaans gespreek (Boesak 2009). En die voormalige MKsoldaat en tans burgemeester van die Breedevallei, Basil Kivedo (2003), het erken dat hy sy “Umkhonto-stryd in Afrikaans gestry" het. Titus (2012) bevestig bruin studente se betrokkenheid: "(T)oe ons as studente in die Wes-Kaap begin het om effek te gee aan 16 Junie 1976, het ons die stryd in Afrikaans gevoer”. Selfs op skool (Le Cordeur et al. 2012:70) was dit Afrikaanssprekende jongmense wat aan die voorpunt was van die struggle.

Sou dit dus te veel gevra wees dat hul kinders hierdie geskiedenis waarby hul ouers eerstehands betrokke was, moet leer in die taal wat hul ouers gepraat het? Dit is nie net die bruin mense wat geïgnoreer is nie. Kaaps, die moedertaal van baie bruin mense, is stelselmatig onderdruk en die situasie word na die skool oorgedra.

\subsection{Kaaps as draer van identiteit}

Alexander (1997) maar ook Ditje en Louw (2004) het lank reeds daarop gewys dat in 'n soeke na identiteit, Afrikaans dikwels as politieke speelbal gebruik is in Suid-Afrika. In hierdie afdeling sal ek aanvoer dat 'n taal so deel is van 'n gemeenskap se identiteit dat dit onmoontlik is om die kinders van daardie gemeenskap se opvoeding te visualiseer sonder dat hul moedertaal ' $n$ inherente deel daarvan uitmaak. Dat Kaaps fasiliteerder is van sy sprekers se identiteit, blyk uit die aanvangstrofe van Patrick Petersen se gedig:

My Xhosa susters en broers, julle moet weet:

gister en vandag het ons 'n lang pad gekom

ons is nie halfnaaitjies nie

ons is Kaaps... (Uit: Ons kom van ver af, 1995:79)

Volgens Pienaar (2014) is Afrikaans vir baie wit Afrikaanssprekers deel van hulle identiteit en definieer dit wie en wat hulle is: Hy sê voorts:

..(t)aal is baie dieper in ons wese en identiteit ingeweef as wat meeste van ons besef. Ons leer nie net taal van mekaar nie, ons leer ook sekere denkpatrone daarmee saam. Ons taal wat ons praat, is dus veel meer as net ' $n$ instrument van klank en kommunikasie. Ons taal is deel van hoe ons onsself beleef en sien, hoe ons onsself uitdruk en verstaan. (Pienaar 2014)

Vir bruin sprekers van Afrikaans is dit nie anders nie (Le Cordeur 2011b), maar hulle het volgens Gerwel (1985) lank reeds vrede gemaak met die andersheid van hul taal. Hulle is minder uitgesproke daaroor en baie min is betrokke by taalstryde. Volgens Kivedo (2003) word "(o)ns voortbestaan nie bedreig deur die afskaling van Afrikaans nie"

Wat hier belangrik is, is die kulturele onderbou van identiteitskepping. Vir baie jare is bruin mense se kultuur geassosieer met die vrolike Klopse karnaval in die Kaap rondom Nuwejaar 
(Carstens \& Raidt 2015). Le Cordeur en Le Roux (2013) wys egter daarop dat dit nie al is waaruit bruin kultuur bestaan nie. As voorbeeld verwys Le Cordeur (2014c) na die ATKV se jaarlikse Rieldans-kompetisie by die Afrikaanse Taalmonument in die eerste week van Desember: "(dis) 'n fees waar meer as 4000 ondersteuners van die totale Afrikaanse gemeenskap die ware vryheid van Afrikaans vier. Afrikaans met al sy variëteite, kleure en geure”. Le Roux en Le Cordeur (2013:55) beklemtoon egter dat die Klopse Karnaval oor baie meer gaan as net jolige vrolikheid: dit is 'n geleentheid vir die eertydse slawe om hulle vryheid wat so duur gekoop is, te vier. Veral die moppie lewer sosiale kommentaar op omstrede aspekte in die samelewing (Le Cordeur \& Le Roux 2013:59). Die moppie Viva Suid-Afrika! verwoord die weerloosheid van die stakers weens sekere vakbonde se leë beloftes oor salarisse. Stakers gaan dikwels voort om te toi-toi sonder dat hulle weet of daar 'n uitkoms sal wees. En tog bly hulle lojaal teenoor Suid-Afrika! In die woorde van Small (1962) verwoord die liedjies die volle lot en noodlot van die mense wat dit praat. Die bevindinge van 'n studie deur Saal en Blignaut (2011) dui daarop dat die gebruik van Tienerkaaps positief ervaar word deur tieners wat Kaaps praat. Die tieners het aangedui Kaaps is "duidelik" en "cool". Dit is volgens Saal en Blignaut (2011) 'n aanduiding van veranderde persepsies oor Kaaps wat sedert 1994 posgevat het.

Alles in ag genome kan daar met sekerheid gesê word dat Kaaps 'n bepaalde status geniet in die samelewing en in die kunste. Kaaps slaag daarin om 'n bepaalde energie los te maak by die bruin, arm, werkersklas Afrikaanssprekendes. Hierdie groep heg baie sentimentele waarde aan die werk van digters, dramaturge en sangers wat in hierdie variëteit werk: Adam Small se Kitaar my kruis (1962) word deur establishment-literatore geloof vir die wyse waarop Kaaps "die diepste beroering van die bruin mense" verwoord (Hugo 2013) en Small se Kanna hy kô hystoe het by die Stellenbosse Woordfees 2014 vol sale getrek.

Die gewildheid van die drama My naam is Ellen Pakkies plaaslik en oorsee en die populariteit van rap en hip-hop kunstenaars soos Brasse van nie Kaap en Hemelbesem spreek vanself. Die sukses van teaterproduksies soos Joe Barber, Plekkie in die son (Marlene le Roux), en Ghoema (Taliep Petersen en David Kramer), die musiek van die Jaloersbokkies en die Rockets, die poësie van Peter Snyders en Patrick Petersen asook jonger digters soos Nathan Trantraal en Ronelda Kamfer getuig van 'n passie vir hulle taal. Du Preez (2011) vat dit as volg saam:

Reclaim your identity! Kaaps has definitely not been erased from South Africa's collective consciousness! It is alive and well! It is enjoyed by people on and off the stage, national TV and in the homes and streets of Cape Town. It is a language that brings about change. It is dynamic and creative. Without a doubt... a language that has a place in our society.

Kaaps is inderdaad ' $n$ belangrike aanduider van identiteit van 'n groot groep van byna 3,3 miljoen Afrikaanssprekendes. Vroeër is verwys na die belangrikheid van onderrig in die kind se moedertaal (Alexander 1997:86, Banda 2001:24, Cummins 2005, Heugh 2006:63). Waar taal dan so belangrik is vir mense en hul identiteit, is dit vanselfsprekend dat dit ook belangrik is vir hulle dat hul kinders in die taal onderrig word. Indien dit nie gebeur nie, lei dit nie net tot spanning nie, maar kom kinders se werklike potensiaal nie na vore nie.

\subsection{Die houding van die Onderwysdepartement}

Vervolgens word gevra waarom die onderwysdepartement nie gehoor gee aan hierdie voor die handliggende, maar ook nagevorste feite nie.

Moppies, afgelei van die Hollandse woord mopje (grappie), is liedjies met satiriese kommentaar op enigiets in die samelewing maar veral op die politieke arena. 
Carstens (in Beeld, 2015) wys ons daarop dat daar in die verlede baie foute gemaak is oor Afrikaans. Die vraag moet gestel word of ons onderwysstelsel nie weer eens fouteer deur steeds bevooroordeeld te wees teenoor die minderheid nie (Mannya 2015:8). Is die houding van die onderwysdepartement jeens Kaaps, soos hierbo uitgewys, nie juis 'n sprekende voorbeeld hiervan nie? Vroeër is aangetoon dat 'n groot deel van die bruin gemeenskap reeds vertroue in Afrikaans verloor het en na Engels emigreer. Wat nodig is, sê Carstens (2015), is 'n nugter debat oor Afrikaans en Kaaps, 'n debat wat nie gekenmerk word deur 'n ontkenning van die verlede en dekades se bevoordeling van Standaardafrikaans nie.

Willemse (2011) wys daarop dat hier, soos ook in Jamaika of verskeie Amerikaanse stede, onderwysers bewus is dat hul leerders se nie-gestandaardiseerde taalvariëteite ekonomies, kultureel en selfs polities gestigmatiseerd is. Hy voer aan dat onderwysers hulle verplig voel om die standaardtaal aan hul leerders te onderrig, anders stel hulle die leerders bloot aan bespotting en lae prestasieverwagtinge. Willemse (2011) beklemtoon voorts die belangrike rol van die onderwys om ruimte vir bemagtiging deur 'n herstel van trots in die eie taal te kweek. Weens die onderwysers se pragmatiese houding verloor leerders stelselmatig die selfvertroue om hul moedertaal te praat. Leerders van die Kaapse Vlakte het dikwels 'n swak selfbeeld omdat hulle nie gemaklik voel met Standaardafrikaans in die onderrigsituasie nie (Willemse 2011).

Onlangse navorsing bewys dat leerders met Kaaps as moedertaal aansienlik swakker vaar as hul eweknieë wat wel in hulle moedertaal (Standaardafrikaans) studeer. Odendaal (2012) se navorsing wys dat kinders van die Kaapse Vlakte in die nasionale assesseringstoetse vir lees onder-presteer. Sy verwys ook na die navorsing van Southwood en Van Dulm (2009) wat daarop dui dat leerders met Kaaps as huistaal onder-gemiddeld (laer as 50\%) presteer het as die geletterdheidstoetse in Standaardafrikaans was. Wanneer die toets herskryf is in Kaapse Afrikaans, het leerders baie beter presteer.

Onderwysers is geleer om Kaapse woorde as spelfoute en taalfoute uit te wys en leerders is gepenaliseer omdat hulle hul moedertaal (Kaaps) gebruik het en tot onlangs het skoolhandboeke woorde in die Kaapse variëteit geïgnoreer (dit is besig om te verander, maar meer hieroor later). Leerders met Kaaps as moedertaal beskou hul taal as minderwaardig en is skaam om aan klasgesprekke deel te neem, of wend hulle tot Engels. Omdat hulle nòg Engels, nòg Standaardafrikaans ten volle magtig is, vaar hulle aansienlik swakker as ander kinders (Le Cordeur 2012; Hendricks 2012). Teen hierdie agtergrond lewer Le Cordeur (2013b, 2015b) 'n pleidooi dat leerders op skool toegelaat word om hulself uit te druk in Kaaps. Atwell, woordvoerder van die Wes-Kaapse Onderwysdepartment (WKOD), reageer as volg:

... dit is ' $n$ interessante voorstel van dr. Le Cordeur, maar nie prakties nie en die WKOD sal voortgaan met Engels, Afrikaans en Xhosa as onderrig- en leertale in die provinsie, in lyn met die nasionale beleid. Ons erken wel die unieke bydrae wat Kaaps tot taalverskeidenheid maak. (Die Burger 2013)

Atwell, namens die WKOD, volstaan dus met die status quo. Sy standpunt toon dat hy nie kennis neem dat kodewisseling tussen twee tale aangewend kan word vir beter begrip nie (Dyers \& Bassey 2015). Net so kan kodewisseling tussen Kaaps en Afrikaans tot beter begrip lei, en 'n institusionele karakter in hierdie skole skep wat meer bevorderlik is vir leer.

Uit die voorafgaande is dit duidelik dat verandering nodig is om, soos Hendriks (2012) dit stel, die ingesteldheid van die onderwysdepartement jeens die gebruik van die variëteite van Afrikaans (soos Kaaps) te destigmatiseer. Hierdie verandering moet begin by die gemeenskap, want die heropbou van die gemeenskap is 'n integrale deel van die veranderingsproses (Le Cordeur 
2013). Kurrikulum is ten diepste verweef met die institusionele kultuur van skole. ${ }^{8}$ As skole dus voortgaan om taalvariëteite te ignoreer deur bv. Kaaps te penaliseer in opstelle en ander skryfwerk, is die institusionele omgewing soos die onderrigtaal nie bevorderlik vir kurrikulumverandering of akademiese sukses nie (Le Cordeur 2014c). Dit geld veral die hantering van Kaaps op die Kaapse vlakte waar die prestasies van leerders in Syfervaardigheid en Geletterdheid baie laag is (vgl. ANA-uitslae 2014).

\section{9 'n Kantelpunt vir Kaaps in die kurrikulum}

In hierdie afdeling sal ek eers die agtergrond skets waarom Kaaps nie in die kurrikulum verreken is nie. Daarna toon ek aan wat na my mening die kantelpunt was vir Kaaps en die vordering wat sedertdien gemaak is.

Uit die houding van die onderwysdepartement hierbo kan afgelei word dat die "bruin stem" gewoon nie deel van die kanon van die Afrikaanse letterkunde kon wees nie, hoofsaaklik omdat Kaaps as 'n dialek of afwyking van Standaardafrikaans beskou is. Gesien teen hierdie agtergrond, was die plek van bruin digters en skrywers wat in Afrikaans skryf, altyd omstrede. Bruin digters soos Adam Small en Peter Snyders wat die struggle-jare oorleef het, se protespoësie was hulle manier om teen hul uitsluiting uit die hoofstroom-Afrikaans te rebelleer. Maar reeds met Small se eerste werke was daar kritiek deur sommige bruin intellektuele dat Small bruin mense sou stereotipeer deur die gebruik van Kaaps (Gerwel 1985). Van Rensburg (2012:130) verwerp hierdie sentiment en noem dat Adam Small en ander skrywers juis Kaaps in hul literêre werke gebruik het, as 'n protes teen Standaardafrikaans. Ander literêre kenners soos Gerwel (1985:16) het ook die kritiek as ongegrond beskou, want Kaaps - soos in Small se drama Kanna hy kô hystoe (1965) - was 'n effektiewe taal van verset teen politieke onreg. Trouens, JC Kannemeyer (Beeld 2012) is van mening dat Kanna een van die heel beste dramas nòg in Afrikaans en een van die beste in die wêreld is. Volgens Hendricks (2012) het Small en Snyders getoon hoe Kaaps 'n draer van grootse letterkunde kan wees. Nog 'n digter, Daniël Hugo (2013), beaam hierdie standpunt en die skrywer Jeanette Ferreira (in Hugo 2013) is van mening dat Small die een skrywer is wat gestalte gegee het aan die krag waarmee Kaaps mense se pyn kan verwoord. Willemse (in Titus 2012) vat dit as volg saam: "Dit gaan daaroor dat mense se waardigheid, en nie net 'n taalvorm nie, erkenning moet kry".

Wat van die "bruin stem" in die nuwe Suid-Afrika gaan word, sal volgens Pakendorf (2011) afhang van "die mate waarin die bewakers van norme bereid is om van die ou heilige koeie (soos standaardafrikaans) af te sien”. Die feit dat Adam Small se oeuvre vir soveel jare geïgnoreer is by die toekenning van Afrikaans se hoogste prys, is die duidelikste voorbeeld van hoe daar teen Kaaps gediskrimineer is. Floris Brown, wat 24 bundels self gepubliseer het (Le Cordeur 2011b), se bitterheid omdat hy deur uitgewers geïgnoreer word, blyk uit die volgende vers:

Mense hou nie daarvan

om woorde te lees wat kwel

aan hul vel,

dus, is ek tot vandag

geen uitgewer se pêl. (Uit: Kaleidoskoop 20119)

\footnotetext{
8 Die institusionele kultuur verwys na daardie aspekte wat leerders laat welkom of onwelkom voel. Taal is een sodanige aspek. Veral leerders wat Kaaps as huistaal het, voel uitgesluit as hul taal geïgnoreer word.

$9 \quad$ Uit sy bundel Kaleidoskoop, 2011.
} 
Die kantelpunt vir Kaaps in terme van sy insluiting in die kurrikulum het na my mening in 2012 gekom. Die destydse voorsitter van die Suid-Afrikaanse Akademie vir Wetenskap en Kuns, Wannie Carstens, het teen alle verwagtinge in sy Raad gevra dat die onreg teen Adam Small reggestel word deur die Hertzogprys aan Small toe te ken selfs al was dit teen die reglement van die Akademie. Die skrywer Abraham de Vries het in reaksie gesê dat Small dit al lankal vir Kanna moes ontvang het omdat hy die een is wat Kaaps tot sy reg laat kom het (Beeld 2012). Deur Kaaps te destigmatiseer, het Small Kaaps verhef tot vryheidstaal, en bowenal literêre taal.

Dit blyk dat die pleidooie van diegene wat argumenteer vir die insluiting van Kaaps in die skoolkurrikulum, nie op dowe ore geval het nie. Daar sal uiteraard omvattende aanpassings moet wees in die skoolkurrikulum. Waar pas die indrukwekkende aantal bruin skrywers en digters in - 'n mens dink aan Adam Small, Peter Snyders, Patrick Petersen, EKM Dido, Nathan Trantaal, Ronelda Kamfer, Betina Wyngaardt en Dianne Ferrus - by 'n veranderde kanon? En sal uitgewers uiteindelik die werk van digters soos Floris Brown publiseer? En volgens watter maatstawwe, vra Pakendorf (2011), sal hulle poësie nou aanvaarbaar wees? Sal leerders wat so lank die geleentheid ontsê is om hierdie skrywers se werk te bestudeer, waardering hê vir hul werk nadat hulle op skool geleer het dat Kaaps onbeskaafd is?

Dit is opmerklik dat Kaaps toenemend sigbaar is in die klaskamer. Vandag word Small - en ander wat in Kaaps skryf - se werk as letterkunde bestudeer. Die gedigte van Marius Titus, Peter Snyders, Adam Small, en onlangs ook die poësie van Patrick Petersen, Nathan Trantaal en Ronelda Kamfer, word reeds op skool bestudeer. Romans soos Diekie vannie Bo-Kaap deur Sulfa OttoAllies (wat afspeel in die Bo-Kaap en die leerder 'n kykie gee in die lewe van 'n Moesliem-gesin), die bekroonde boek van Betina Wyngaardt, Troos vir die Gebrokenes (wat die leerder inlig oor die lewe van 'n arm bruin gesin in 'n bruin Township op die platteland), Gerook deur die joernalis Eldridge Jason ('n verhaal oor die lewe van 'n bendelid) asook dramas van Adam Small (Krismis van Map Jacobs en Kanna hy kô hystoe) vorm deesdae deel van die letterkunde-kurrikulum op universiteite en in skole.

Hierdie skrywers se werk word oral opgevoer, en bekende teaters soos die KunsteKaap voer hul werk wat in skole voorgeskryf word, op en nooi leerders en studente uit in 'n poging om literêre werke in Kaaps aan alle leerders bekend te stel en na 'n groter gehoor te neem. Kaaps is dus deel van die skoolkurrikulum gemaak terwyl erkenning gegee is aan die ryke geskiedenis en erfenisse van hierdie land.

Op die gebied van Taalleer kry Kaapse woorde vir die eerste keer wyer erkenning. So is daar in die jongste Afrikaanse Woordelys en Spelreëls (AWS) ongeveer 80 Moesliem-woorde opgeneem. En 'n halfeeu nadat die eerste Verklarende Handwoordeboek van die Afrikaanse Taal (HAT) verskyn het, is dit die eerste keer dat so baie Kaapse variante in dié gesogte Afrikaanse woordeboek verskyn. Kaapse, maar ook Moesliem-woorde soos "kwaailappies”, “mang”, "berk", "ghoema”, "papgeld", "tamaaf" en "skanghagha", wat al baie jare in die Kaapse bruin gemeenskap gebruik word, pryk vir die eerste keer in dié HAT (Le Cordeur 2015b).

Hoewel Kaapse idome en uitdrukkings opgeneem is in die nuwe Platinum- handboekreeks, ${ }^{10}$ sal groter waardering vir Kaapse taalstrukture (deur onder meer nie leerders se gebruik van die besitlike voornaamwoord onse taal, as foutief te merk nie) ook tot meer sukses by hierdie leerders lei. Daar kan ook vir die ander variante voorsiening gemaak word deur ook van daardie woorde in die handboeke en HAT op te neem terwyl die werk van skrywers soos Anzil Kulsen wat pragtige romans oor die Namakawalandse mense skryf - boonop in hul eie variëteite - in Noord-Kaapse skole se kurrikulum opgeneem behoort te word.

10 Le Cordeur et al. 2014. Platinum Afrikaans Huistaal, graad 9, Pearston: Kaapstad. 


\section{SLOTWOORD}

Taal is een van die vernaamste uitdagings wat in die pad staan van akademiese sukses. Dit, ten spyte van Suid-Afrika se Taalbeleid wat stipuleer dat taal nie in die pad moet staan van leer nie (RSA, 1996). Afrikaans het talle variëteite. Kaaps, maar ook al die ander variëteite (insluitend standaardafrikaans) verdien om bewaar te word en moet derhalwe al die ruimte gegun word wat nodig is om maksimaal te ontwikkel (Le Cordeur 2015b). Gevolglik was dit nodig om een van Afrikaans se bekendste variëteite - Kaaps - te ondersoek, en veral hoe dit beleef en ervaar word deur sy sprekers in hulle alledaagse omgang met die taal en die impak daarvan op die leerders met Kaaps as moedertaal in die klaskamer. Vanuit die literatuur wat in hierdie studie bestudeer is, is dit duidelik dat die kind wat met Kaaps grootgeword het, tot dusver benadeel is in die skool. Die onus rus nou op die sprekers van Afrikaans om aan Kaaps sy regmatige plek binne Afrikaans te besorg.

Nog eens: daar word wêreldwyd aanvaar dat leer deur die moedertaal die mees effektiewe manier van leer is wat die beste resultate lewer (Alexander 1997, Heugh 2006). As dit waar is van Engels, Afrikaans en die ander inheemse tale, dan geld dieselfde argument ook vir Kaaps. Baie is al gedoen om wyer erkenning aan Kaaps te gee in die klaskamer. Suid-Afrikaanse onderwys het egter nog 'n lang pad om te loop voordat leerders met Kaaps as moedertaal sal tuisvoel in die klas.

Indien Kaaps erkenning kry in die kurrikulum bied dit die ideale geleentheid om die doelwitte en beginsels van die KABV uit te leef. Nie net sal dit by Suid-Afrikaanse leerders ' $n$ waardering kweek vir ons inheemse kennissisteme nie; dit sal ook erkenning gee aan die ryke geskiedenis en erfenisse van hierdie land as bydraende faktore om die waardes in die Grondwet te laat gedy (DvBO 2012:5).

Die Departement van Basiese Onderwys het 'n baie goeie begin gemaak om Kaaps in die kurrikulum te verreken veral op die gebied van die letterkunde. Hierdie proses moet voortgesit en uitgebrei word na Taalleer. Om dit te vermag, vereis Afrikaans-onderrig op skool 'n meer inklusiewe benadering as wat tans die geval is. Nie net skep dit geleentheid om die verdeeldheid van die verlede te heel nie; dit sal beslis ook help om die volle potensiaal van elke leerder te ontsluit soos deur die Grondwet van Suid-Afrika voorgeskryf.

\section{BIBLIOGRAFIE}

Alexander, N. 1997. Language policy and planning in the new South Africa. African Sociological Review, $1(1): 82-98$.

Banda, F. (ed). 2001. Language across Borders. Cape Town: The Centre for Advanced Studies of African Society (CASAS nr.12).

Bamgbose, A. 2000. Language and exclusion: The consequences of language policies in Africa. London: Transaction.

Bransford, J.D., A.L. Brown \& R.R. Cocking. 2000. How people learn: Brain, mind experience and school. Washington, DC: National Academy Press.

Beeld, 2012. Hertzogprys vir Adam Small. Beeld, 23 Maart: 3.

Boesak. Allan. 2009. Running with Horses: Reflections of an Accidental Politician. Cape Town: Joho! Publishers.

Bourdieu, P. 1991. Language and symbolic power. Harvard: Harvard University Press.

Carstens, W.A.M. 2011. Norme vir Afrikaans. Enkele riglyne by die gebruik van Afrikaans. Pretoria: Van Schaik Uitgewers.

Carstens, W.A.M. \& E.H. Raidt. 2015. Die storie van Afrikaans: uit Europa en van Afrika. Pretoria: Protea Boekhuis.

Carstens, Wannie. 2015. Akademia moet versigtig wees om uit te sluit. Rapport Weekliks, 22 Maart: 11.

Cummins, J. 2005. Affirming identity in multilingual classrooms. Educational Leadership, September, 3843. 
Davids, A. 2011. The Afrikaans of the Cape Muslims from 1815 to 1915 - A sociolinguistic study. (H. Willemse \& S.E. Dangor eds). Pretoria: Protea Boekhuis.

Dekker, G. 1966. Afrikaanse Literatuurgeskiedenis. Kaapstad: Nasou.

Deurmert, A. 2004. Language standardization and language change: the dynamics of Cape Dutch. Amsterdam: Benjamins Publishing.

Du Plessis, I.D. 1935. Die bydrae van die Kaapse Maleiers tot die Afrikaanse volkslied. Nasionale Pers: Kaapstad.

Du Preez, Madge. 2011. Breaking through the language barrier - "kaapse afrikaans": a tool to effect change in society. Afrikaaps:ABRAXAS, 11 Junie.

DvBO (Departement van Basiese Onderwys) 2012. Kurrikulum-Assesserings en beleidsverklaring (KABV): Afrikaans Huistaal Graad 10 -12. Pretoria: Staatsdrukker.

Dyers, C. \& A. Bassey. 2015. Using isiXhosa and Afrikaans as auxiliary languages in teaching Linguistics to undergraduate students at UWC. (Lopende projek).

Hambidge, Joan. 2013. Chokers en Survivors: Kaaps en in your face. Resensie, LitNet: 3 Julie.

Gerwel, G.J. 1985. Van Petersen tot die hede - 'n kritiese bestekopname. In: Smith, Julian, e.a. (reds.) Lesing gelewer tydens simposium van Swart Afrikaanse skrywers by die Universiteit van Wes-Kaapland, Bellville: bl. 11-21.

Giliomee, Herman. 2014. Die troebele toekoms van die Afrikaners en Afrikaans. Tydskrif vir Geesteswetenskappe, 54(4):571-595.

Hendricks, F. 2009. Om die miskende te laat ken: 'n blik op Adam Small se literêre verrekening van Kaaps. Tydskrif vir Letterkunde. 49 (1) 2012: bl. 95.

Hendricks, F. 2012. Die aard en konteks van Kaaps: 'n verledetydse, eietydse en toekomsperspektief. Lesing gelewer tydens simposium Kaaps in fokus, 19-20 Julie 2012, Universiteit van Wes-Kaapland, Bellville.

Heugh, K. 2006. Die prisma vertroebel: Taalonderrigbeleid geïnterpreteer in terme van kurrikulumverandering. Tydskrif vir Geesteswetenskappe, 46(2):63-76.

Hugo, Daniel (red.). 2009. Halala Afrikaans. Pretoria: Protea Boekhuis.

Jason, Eldridge. 2013. Gerook. Pretoria / Kaapstad: LAPA Uitgewers.

Kapp, Pieter. 2013. Maties en Afrikaans: 'n Besondere verhouding, 1911 - 2011. Pretoria: Protea Boekhuis.

Kivedo, B. 2003. Wie is die bruin gemeenskap? LitNet. Beskikbaar aanlyn by [www.oulitnet.co.za/seminaar/ kknkkivedo.asp].

Kotzé, Ernst. 2014. Afrikaans as besitting, en die vraagstuk van herstandaardisering. Tydskrif vir Geesteswetenskappe, Vol. 54 (4) Des 2014:635-655.

Le Cordeur, M.L.A. 2011a. Die variëteite van Afrikaans as draers van identiteit - 'n Sosiokulturele perspektief. Tydskrif vir Geesteswetenskappe, Vol. 51 (4) Des 2011.

Le Cordeur, M.L.A. 2011b. Die rol van die bruin mense in die ontwikkeling van Afrikaans . Referaat gelewer by die Afrikaanse Festival, 17 - 19 Junie, Amsterdam.

Le Cordeur, M.L.A. 2012. Kaaps in Fokus: Verrekening van variëteite in die Onderwys. Lesing gelewer tydens simposium Kaaps in fokus, 19-20 Julie 2012, Universiteit van Wes-Kaapland, Bellville.

Le Cordeur, M.L.A. 2013. Erken Kaaps as taalvariëteit. Die Burger: 6 Julie: 8.

Le Cordeur, M.L.A. \& M. le Roux 2013. Die Klopse van Wellington; 100 jaar se onvertelde stories. Kaapstad: Naledi.

Le Cordeur et al., 2014a. Platinum Afrikaans Huistaal, graad 9. Kaapstad: Pearson.

Le Cordeur, M.L.A. 2014b. Kaaps: a variety of Afrikaans that underpins the individual and collective identities of the people on the Cape Flats. SAALT Kongres, 1 - 4 Julie, Stellenbosch Universiteit.

Le Cordeur, M.L.A. 2014c. Is Afrikaans almal se taal? Referaat by die Simposium deur die SA Akademie vir Wetenskap en Kuns: 17 Januarie. Universiteit Pretoria.

Le Cordeur. M.L.A. 2015a. 'n Krities-analitiese beskouing van bruin Afrikaanssprekendes se rol in die Afrikaanse media en Naspers, in Rabe, L. (red.). 'n Konstante Revolusie: Naspers, Media 24 en oorgange. Kaapstad: Tafelberg.

Le Cordeur, M.L.A. 2015b. Haal politiek uit taal; erken ook Kaaps. Rapport: 20 September: 3.

Le Cordeur, M.L.A, R. Olivier, D. Prinsloo \& J. van der Elst (reds.). 2012. 16 Junie 1976. 35 jaar later. Pretoria: SA Akademie vir Wetenskap en Kuns. 
Le Cordeur M.L.A., D. Lawrence, D. Cloete \& R. van Oordt. 2014. Hoofstuk 2: Afrikaans - Mites en werklikhede (p.29 -68). In Afrikaansmetodiek deur 'n nuwe bril : 'n handleiding vir Afrikaansonderwysstudente. Pretoria: Oxford University Press.

Lin, G. 2009. Higher Education Research Methodology-Literature Method. International Education Studies, 2(4):179-181.

Mannya, Modidima. 2015. Rassisme is hier omdat dit nooit verdwyn het nie. Rapport Weekliks, 29 Maart: 8.

Mehrotra, S. 1998. Education for All: Policy Lessons From High-Achieving Countries, UNICEF Staff Working Papers, New York, Unicef.

Odendaal, Gerda. 2012. Die herstandaardisering van Afrikaans. Ongepubliseerde PhD-proefskrif. Stellenbosch: Universiteit Stellenbosch.

Odendaal, Gerda. 2014. Moet Afrikaans geherstandaardiseer word? Tydskrif vir Geesteswetenskappe, Vol. 54 (4) Des 2014:656-674.

Otto-Sallies, Zulfa. 1997. Diekie vannie Bo-Kaap. Kaapstad: Tafelberg.

Pakendorf, Gunter. 2011. Grond/Santekraam. LitNet Akademies-resensie-essay:10 November. Aanlyn beskikbaar by [http://www.litnet.co.za/Article/litnet-akademies-resensie-essay-grondsantekraam].

Pienaar, Abel. 2014. Kop en hart: Taal van my hart. Rapport.18 April: 9.

Petersen, S.V. 1959 (1944). Die enkeling. Kaapstad: Maskew Miller Longman.

Rapport. 2013a. Net suurknolle leef sonder grappe. Rapport, 13 Julie: 10.

Rapport. 2013b Kaaps behoort aan 'n iedere. Rapport, 11 Augustus: 11.

RSA (Republiek van Suid-Afrika). 1996. Die Grondwet van die Republiek van Suid-Afrika. Nr. 108 van 1996. Pretoria: Staatsdrukker.

Saal, Elvis \& Joline Blignaut. 2011. "Moetie rai gammattaal gebrykie": Die gebruik en waarde in gedrukte advertensies. LitNet Akademies, 8(3): Desember.

Small, Adam. 1962. Kitaar my Kruis. Kaapstad: HAUM.

Small, Adam. 1965. Kanna hy kô hystoe. Kaapstad: Tafelberg.

Small, Adam. 1987. Krismis van Map Jacobs. Kaapstad: Tafelberg.

Titus, Danny. 2012. Kaaps is tog te poenankies. Artikel oor die Kaaps-konferensie by die Universiteit van Wes-Kaapland, 19-20 Julie. Rapport, 27 Julie: 12.

Van Rensburg, M.C.J. 1992. Die demokratisering van Afrikaans. In V.N. Webb (red.). Afrikaans nà Apartheid. Pretoria: J.L. Van Schaik, bl. 181-197.

Van Rensburg, Christo. 2012. So kry ons Afrikaans. Pretoria: Protea Boekhuis.

Webb, V. 2006. Perspektiewe op moedertaalonderrig. Tydskrif vir Geesteswetenskappe, 46(2):37-50.

Willemse, Hein. 2011. Referaat: Gelewer tydens die 1ste Jaarvergadering van die Kaapse Kunste- en Uitsaaiassosiasie (KKUA) en Radio Kaap se Punt, 16 Julie.

Wyngaardt, Betina. 2009. Troos vir die gebrokenes. Kaapstad: Umuzi. 